\title{
An Investigation into Mechanical Properties of Ductile Cast Iron with Different Heat Treatment Processes
}

\author{
Romany R. Moussa ${ }^{1,2^{*}}$, Amer E. Ali ${ }^{3}$, Ragab K. Abdel-Magied ${ }^{3}$, Mohamed N. Elshiekh ${ }^{1}$ \\ 1 Department of Production Technology, Faculty of Industrial Education, Beni-Suef University, \\ 62511 Beni-Suef, Salah Salem St., Egypt \\ 2 Department of Materials Science and Engineering, Faculty of Mechanical Engineering, \\ Budapest University of Technology and Economics, H-1521 Budapest, P.O.B. 91, Hungary \\ ${ }^{3}$ Department of Mechanical Engineering, Faculty of Engineering, Beni-Suef University, 62511 Beni-Suef, Salah Salem St., Egypt \\ * Corresponding author, e-mail: eng.romany87@gmail.com
}

Received: 31 December 2018, Accepted: 18 March 2019, Published online: 27 May 2019

\begin{abstract}
The mechanical properties as well as microstructure of the ductile cast iron ( $\mathrm{DCl})$ are most likely affected by heat treatments. In this work, the mechanical properties of different heat treated of DCl alloy were investigated. Two heat treatment (HT) processes were conducted for $\mathrm{DCl}$; austempering and quenching followed by lower tempering. The melted alloy of DCl was poured in Y-block, from which the specimens of the mechanical tests were prepared. Experimental tests were carried out to investigate the effect of these HT processes on the mechanical properties. A comparison between mechanical properties due to $\mathrm{HT}$ and as cast DCl are presented and discussed. The results showed that there is a difference in microstructure, homogeneity, wear rate and compression of DCl based on the conducted heat treatment.
\end{abstract}

\section{Keywords}

heat treatment, $\mathrm{DCl}$ (Ductile Cast Iron), quenching, tempering, austempering

\section{Introduction}

Ductile cast iron is one of the most important materials, which is used in many industrial and automobile applications. Recently, it was found that heat treatment of alloyed cast iron improves the hardness, wear resistance and reduces friction coefficient [1].

The applications of ductile cast iron with heat treatments especially austempering process are very interesting. Product examples have been discussed along with the specific material that results in their choice over competitive materials [2].

The mechanical properties of dual phase austempered ductile iron at different matrices have been investigated by Basso et al. [3].

A standard Y-block was used for the research and the results reveal that there is a significant increment in fatigue, tensile strength, yield strength, and fracture toughness.

Experimental investigation was conducted on $600 / 3$ and 500/7 grades of ductile cast iron austenized and quenched in different media (vegetable, mineral oil, and water). The results reported that changes have been obtained in yield stress, elongation, hardness, and tensile to study of the effect of different cooling rates by changing quenching media [4].

The effects of austempering, normalizing and annealing heat treatment processes on ductile iron specimen have been studied, in which various temperatures and holding times are adopted. They reported that the maximum hardness is observed in austempered ductile iron specimen while minimum hardness value is observed in annealed specimen. Moreover, it is observed that the tensile strength is maximum in normalized specimen while minimum in annealed ductile iron specimen [5].

Nodular cast iron alloy was investigated with special chemical composition and heat treated by austempering processes and fast quenching to avoided perlitic transformation. The results reported that there are changes in tensile strength with high performance in hardness and impact energy [6].

Mechanical properties of an austempered ductile cast iron alloyed with copper and molybdenum have been 
investigated. The specimens were austenized at $910{ }^{\circ} \mathrm{C}$ for $90 \mathrm{~min}$ and soaked in salt bath in different ranges of temperature. The results revealed that there is an increasing in ductility with highest austempering temperature, in addition, the tensile strength was increased with lowest temperature as well [7].

Study of a single step austempering and two-step high-low temperature regimes has been carried out. They reported that with increasing austempering temperature, the morphology of microstructure changes from a circular or lath to feathery. Moreover, the impact properties of a two-step austempered spheroidal graphite (SG-cast) iron are significantly influenced by the second step austempering temperature and time $[8,9]$.

Evidently, most of the published works adopt the austempered heat treatment as a method for enhancement of mechanical properties of DCI, while the quenching followed by tempering (Q-T) heat treatment compared with other heat treatment processes was overlocked to investigate the mechanical properties of DCI. This is the motivation of this research. In this work, two heat treatment processes were conducted for DCI; austempering and quenching followed by lower tempering. The effect of two HT on DCI were presented and discussed in details in the following sections.

\section{Experimental Work}

\subsection{Materials}

In this work, the experimental material was melted in electric induction furnace (Inductotherm) with oneton capacity. The ductile cast iron alloy was produced by melting Sorel pig iron and ductile cast iron returns as a row material, while the additives are carburizer, iron silicon (FeSi), nickle-magnesium (NiMg), Supper seed as well as the steel scraps.

The melted DCI alloy was poured in Y-block shape $50 \mathrm{~mm}$ thickness formed in sand cavity mould as shown in Fig. 1 and its chemical composition is illustrated in Table 1.

\subsection{Specimens preparations}

The specimens were cut from Y-block to different shapes according to the test types as follows:

- The tensile test specimens, as shown in Fig. 2, were fabricated to bars using wire cut and machined to the final bone shape using conventional turning machines.

- The compression test specimens were fabricated in cylindrical shape by wire cut with dimensions $13 \mathrm{~mm}$ in diameter and $25 \mathrm{~mm}$ in height based on ASTM standard [11].
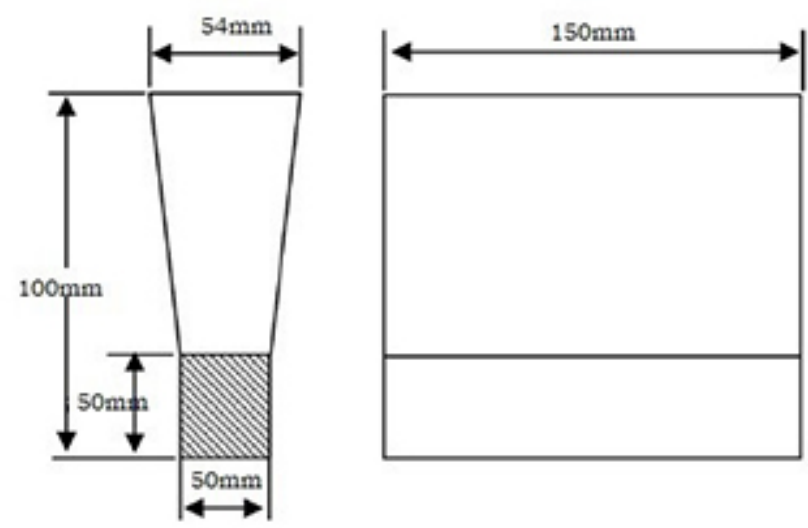

Fig. 1 Y-block specimen as cast

Table 1 Chemical composition of the specimen measured by spectrometer ARL 2400

\begin{tabular}{lcccccccc}
\hline Element & $\mathrm{C}$ & $\mathrm{Si}$ & $\mathrm{Mn}$ & $\mathrm{P}$ & $\mathrm{S}$ & $\mathrm{Ni}$ & $\mathrm{Cr}$ & $\mathrm{Mg}$ \\
\hline$\%$ & 3.79 & 2.77 & 0.11 & 0.02 & 0.003 & 0.96 & 0.03 & 0.03 \\
\hline
\end{tabular}
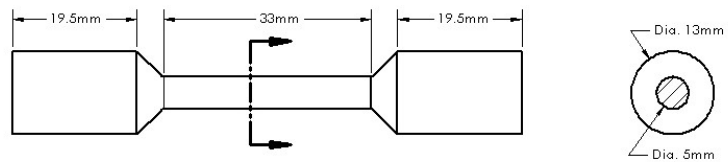

Fig. 2 Tensile test specimen as cast dimensions
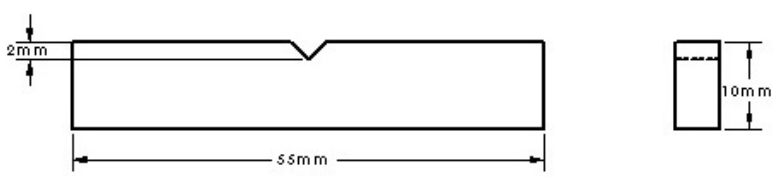

Fig. 3 Impact test specimen as cast dimensions

- The impact test specimens, as illustrated in Fig. 3, and wear test specimens were produced based on ASTM [12].

\subsection{Heat Treatment}

In this work, two heat treatment processes were done to investigate the effect of heat treatment on the characteristics of the ductile cast iron under consideration. These treatment processes were austempering and quenching followed by tempering with different sequences as follows in Sections 2.3.1, 2.3.2.

\subsubsection{Austempering process}

Fig. 4 depicts the Austempering process, in which the specimens come after in time as following sequences:

- heating to the austenitization temperature at $910{ }^{\circ} \mathrm{C}$ (A to B)

- holding time at the austenitization temperature for $15 \mathrm{~min}$ (B to C) 


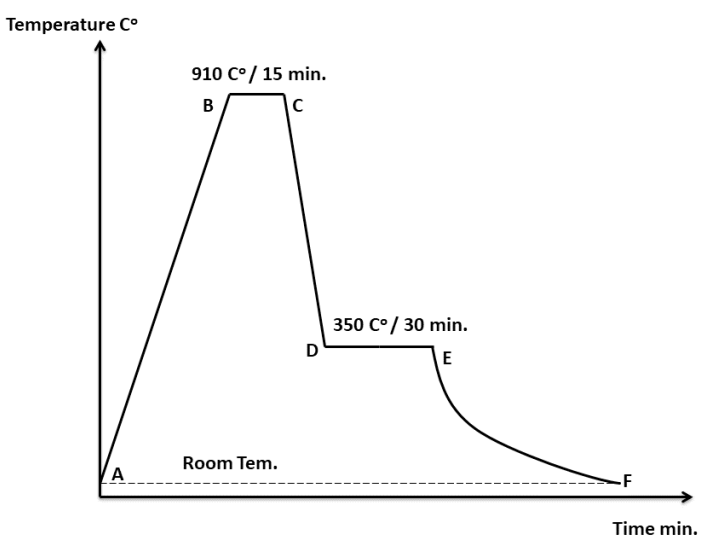

Fig. 4 Austempering process

- quick cooling in salt bath to the temperature of isothermal transformation in at $350{ }^{\circ} \mathrm{C}$ (C to D)

- holding time at this temperature for $30 \mathrm{~min}$ (D to $\mathrm{E}$ )

- cooling to the ambient temperature (E to F).

\subsubsection{Quenching followed by tempering}

Fig. 5 demonstrates the quenching process that was followed by tempering, in which the specimen goes though in sequences as following:

- heating to the austenitization temperature at $910^{\circ} \mathrm{C}$ (A to B)

- holding time at the austenitization temperature for $15 \min (\mathrm{B}$ to $\mathrm{C})$

- quick cooling in solten bath to the temperature of isothermal transformation of austenite $200{ }^{\circ} \mathrm{C}$ (C to D)

- holding time at this temperature for $20 \mathrm{~min}$ (D to $\mathrm{E}$ )

- cooling to the ambient temperature (E to F)

- reheating in salt bath to reach tempering temperature $350{ }^{\circ} \mathrm{C}$ ( $\mathrm{F}$ to $\mathrm{G}$ )

- holding time at this temperature for $30 \mathrm{~min}(\mathrm{G}$ to $\mathrm{H})$

- cooling to the ambient temperature (H to I).

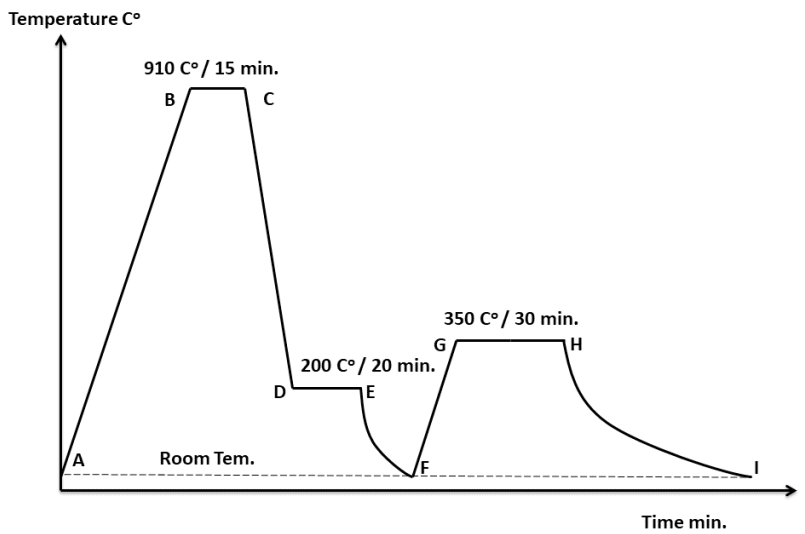

Fig. 5 Quenching follow by Tempering process

\subsection{Experimental Tests}

Several experimental tests were carried out to investigate the mechanical characteristics of specimens in different conditions considered in this work. It should be pointed to the tensile, compression, wear, and impact tests were conducted at room temperature to show the difference in the mechanical properties of the as-cast, austempered, and Q-T of DCI, with comparison among them. These tests are as follows:

- Tension and Compression test: tension and compression tests were carried out using UH-50 A SHIMADZU universal testing machine with loading range 0 to $490 \mathrm{KN}$.

- Impact test: to measure the fracture energy, the impact strength test was conducted using MAT 20 BROOKS IZOD machine with maximum energy $15 \mathrm{~J}$.

- Wear test: Abrasive wear test was carried out by pin-on-disc device, in which the wear specimen was held vertically against the rotating disc under load $20 \mathrm{~N}$ for $3 \mathrm{~min}$, rotation speed $150 \mathrm{rpm}$, and track diameter $160 \mathrm{~mm}$.

\section{Results and Discussion}

\subsection{Microstructure analyses}

Fig. 6 shows the microstructure of the specimen in different conditions e.g. as-cast, austempered, and Q-T of DCI. The graphite nodules are presented in as cast microstructure etched in $2 \%$ Nital. As illustrated in Fig. 6 (a), after austempering heat treatment, the entire matrix was transformed to plate like shaped ausferrite structure as shown in Fig. 6 (b).

This kind of a matrix structure provides higher strength and ductility as compared to as-cast ductile cast iron, while after Q-T heat treatment process, the entire matrix was transformed to martensitic structure as shown in Fig. 6 (c). This kind of a matrix structure enhances the mechanical properties.

Fig. 7 shows the effect of the heat treatment on the compression property of the DCI. It could be seen from the Fig. 7 that the austempered sample is higher in compression load than the as-cast one while the Q-T sample is higher in compression than both as cast and austempered one. This is because the carbon stabilized in austenite zone was transformed to martensitic structure that was increased the surface compressive stress.

The effect of HT on the wear rate of DCI in the considered conditions is presented in Fig. 8. The Fig. 8 reflects that the wear rate in Q-T sample is lower than the austempered one, rather than the as-cast one. This referred to the lower temperature of soaking lead to higher carbon 


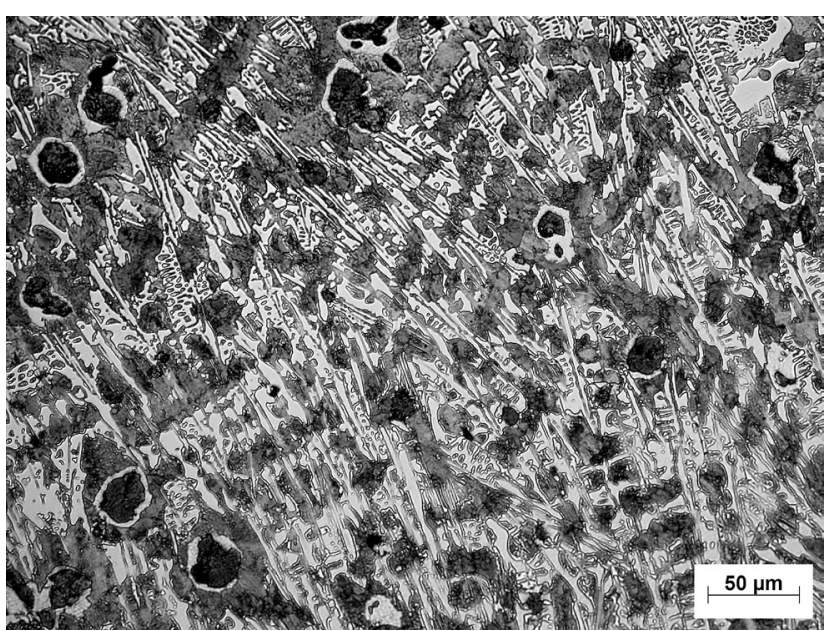

(a)

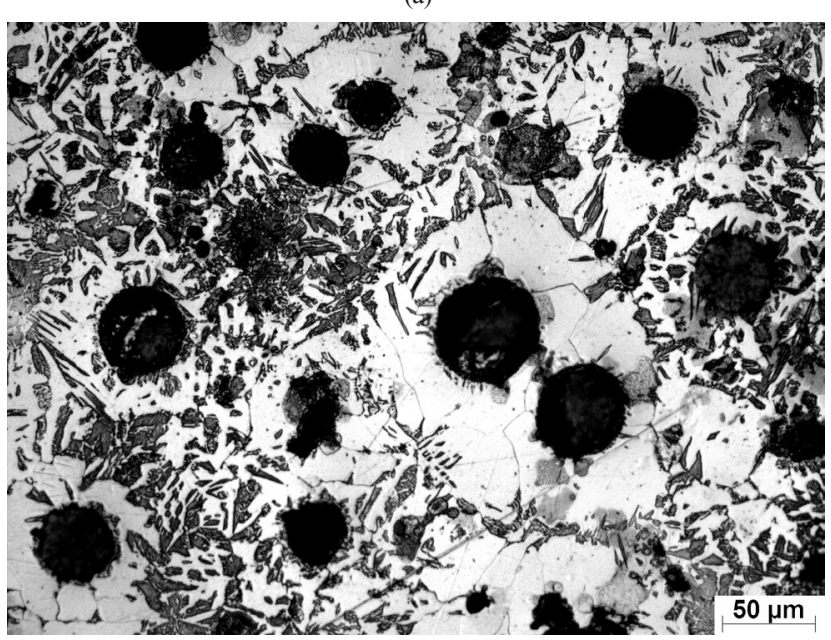

(b)

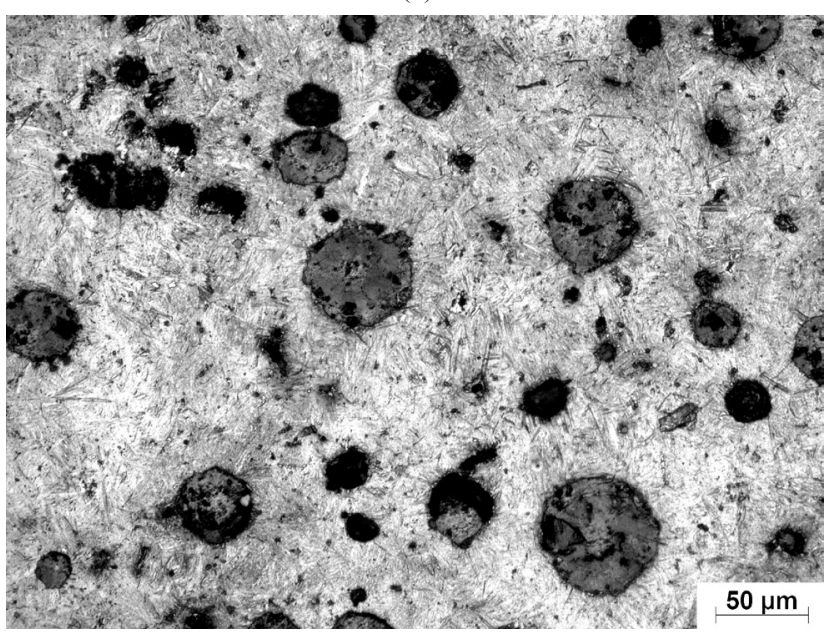

(c)

Fig. 6 Microstructure of the specimens in different conditions (a) As cast etched in $2 \%$ Nital

(b) Austempering HT after etched in $2 \%$ Nital

(c) Q-T HT after etched in $2 \%$ Nital

amount trapped in the martensitic phase and lower volume loss due to wear.

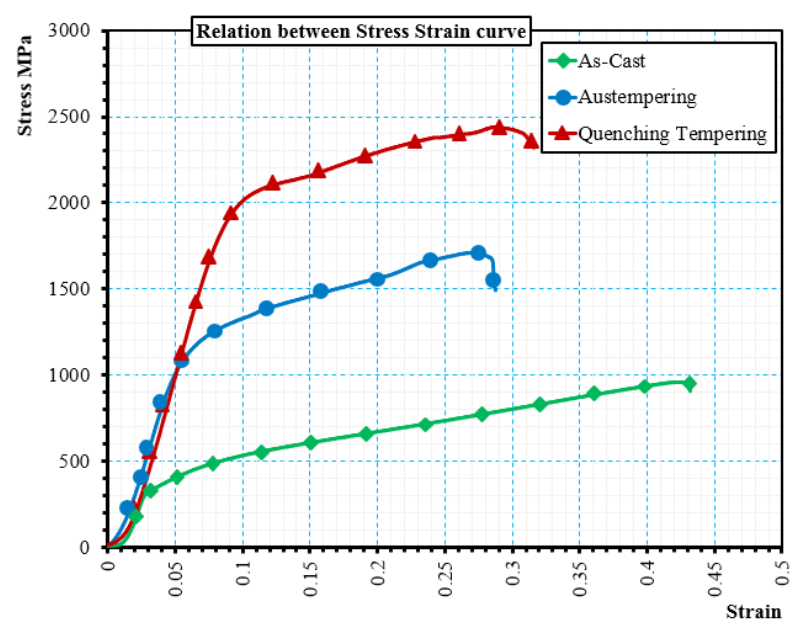

Fig. 7 Compression load of the specimens in different conditions

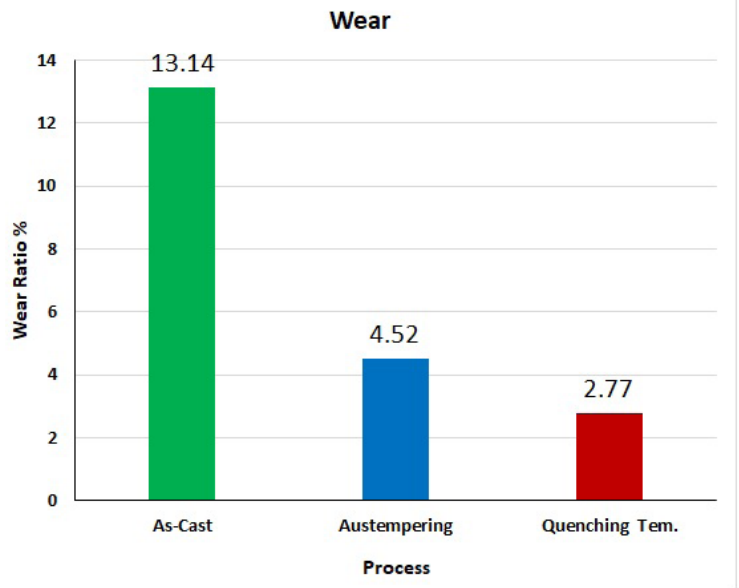

Fig. 8 Wear ratio of the specimens in different conditions

Fig. 9 depicts the impact energy for all types of heat treatments. Fig. 9 reflects the homogeneity of the DCI structure in the considered conditions. This is clear from the convergence of the energy readings to each other, i.e. in as-cast samples there is a difference in readings, this difference decreases in case of Q-T condition while in austempered DCI this difference declined and the reading are converged. This indicates that the homogeneity in austempered is very good than the Q-T and both are better than as-cast DCI.

Table 2 concludes the difference in mechanical properties of the specimens on the considered conditions of this work. It could be read from the Table 2 that the ultimate tensile strength (UTS) of as-cast sample is $535 \mathrm{MPa}$. Austempered samples were found to be higher in UTS, while Q-T samples were found to be higher in UTS than austempered samples and higher than the as-cast specimens. This referred to that the tensile strength increasing with lower soaking temperatures. The average of 


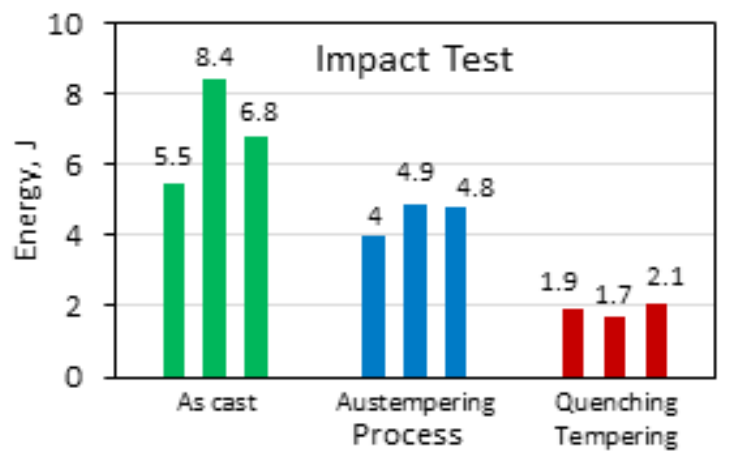

Fig. 9 Impact test results of the specimens in different conditions

Table 2 Mechanical properties of DCI specimens in different conditions

\begin{tabular}{lccc}
\hline Condition & UTS $(\mathrm{MPa})$ & Impact Energy $(\mathrm{J})$ & Wear ratio \% \\
\hline As-Cast & 535 & 6.9 & 13.14 \\
Austempering & 1291 & 4.6 & 4.52 \\
Quench. Temp. & 1304 & 1.9 & 2.77 \\
\hline
\end{tabular}

the impact energy for the Q-T is very low regarding the as-cast rather than the austempering condition, because the low soaking temperature makes structure with low absorption energy. In addition, the wear rate of the Q-T

\section{References}

[1] Mohamed, I. A., Ibraheem, A. A., Khashaba, M. I., Ali, W. Y. "Influence of Heat Treatment on Friction and Wear of ductile Iron: I. Role of Copper and Molybdenum", International Journal of Control, Automation and Systems, 2(3), pp. 23-30, 2013.

[2] Hayrynen, K. L., Brandenberg, K. R., Keough, J. R. "Application of Austempered Cast Iron", AFS Transaction, 110, pp. 1-10, 2002.

[3] Basso, A., Caldera, M., Chapetti, M., Sikora, J. "Mechanical Characterization of Dual Phase Austempered Ductile Iron", ISIJ International, 50(2), pp. 302-306, 2010.

[4] Madtha, L. S., Babu, B. R. N. "Experimental Behavioural Study of Ductile Cast Iron Microstructure and its Mechanical Properties", International Journal of Engineering Research and Applications (IJERA), 3(3), pp. 1470-1475, 2013.

[5] Rao, S. V., Venkataramana, M., Kumar, A. C. S. "Effect of Heat Treatment Processes on Ductile Cast Iron Mechanical Properties - an Experimental Approach", International Journal of Advanced Technology in Engineering and Science, 2(12), pp. 221-226, 2014.

[6] Avdusinovic, H., Gigović-Gekić, A. "Heat Treatment of Nodular Cast Iron", In: $13^{\text {th }}$ International Research / Expert Conference "Trends in the Development of Machinery and Associated Technology", TMT 2009, Hammamet, Tunisia, 2009, pp. 669-672.

[7] Kim, Y-J., Shin, H., Park, H., Lim, J. D. "Investigation into Mechanical Properties of Austempered Ductile Cast Iron (ADI) in Accordance with Austempering Temperature", Materials Letter, 62(3), pp. 357-360, 2008

https://doi.org/10.1016/j.matlet.2007.05.028 specimen is lower than austempering, subsequently, as-cast. This referred to hardenability of the due to Q-T heat treatment process than the other process.

\section{Conclusion}

Two heat treatment processes; austempering and quenching followed by tempering were conducted for DCI. Experimental tests were carried out to investigate the effect of these heat treatments processes on the mechanical properties compared with the as-cast DCI. The finding of this work could be concluded as follows:

- Austempered sample is higher in compression stress than the as-cast one while the Q-T sample is higher than both.

- The impact energy of austempered sample is high in energy absorption than the Q-T sample and the homogeneity in austempered is very good than the Q-T and both are better than as cast DCI.

- The wear resistance of austempered specimen is higher than the as-cast one, while the Q-T is the highest resistance of wear from austempered and as cast specimens.

[8] Hafiz, M. "Enhanced Mechanical Properties of Austempered Sg-Cast Iron by Two-Step Austempering Heat Treatment", Journal of Al Azhar University Engineering Sector, 5(14), pp. 49-58, 2010.

[9] Hafiz, M. "Effect of Second Step Austempering Temperature and Time on the Impact Properties of Two-Step Austempered Sg-Cast Iron", Journal of Al Azhar University Engineering Sector, 5(14), pp. 59-65, 2010.

[10] ASTM International "ASTM A536-84(2009) Standard Specification for Ductile Iron Castings", ASTM, West Conshohocken, PA, USA, 2009. https://doi.org/10.1520/A0536-84R09

[11] ASTM International "ASTM E9-89a(2000) Standard Test Methods of Compression Testing of Metallic Materials at Room Temperature (Withdrawn 2009)", ASTM, West Conshohocken, PA, USA, 2000. https://doi.org/10.1520/E0009-89AR00

[12] ASTM International "ASTM E23-12 Standard Test Methods for Notched Bar Impact Testing of Metallic Materials", ASTM, West Conshohocken, PA, USA, 2012. https://doi.org/10.1520/E0023-12 